\title{
Estimation of Student Satisfaction and Student Loyalty in Indian University offering Higher Education
}

\author{
Dhaval Gaud $^{1 *}$ and Dr. Bijal Zaveri ${ }^{2}$

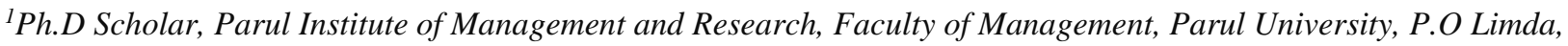 \\ Waghodia, Vadodara, Gujarat-391769 \\ ${ }^{2}$ Dean and Director, Faculty of Management Studies, Parul University, P.O Limda, Waghodia, Vadodara, Gujarat-
} 391769

\begin{abstract}
Thanks to its multidimensional nature and ultimate effect on customer retention, consumer engagement, and finally, firm efficiency, service value has gained a lot of attention in recent marketing literature. The findings indicate as the service value dimensions functional value, consumer satisfaction, service efficiency, appurtenant value, image, and social value. This study supports the notion that higher education institutes can achieve a competitive advantage by focusing on value for service.
\end{abstract}

Keywords: student satisfaction; student loyalty; higher education; India; University

\section{INTRODUCTION}

India has the world's third highest higher education network, next behind China and the US (Reddy et al., 2016). The Indian higher education system offers education and training in a variety of subject areas such as the arts and humanities, natural, mathematical and social sciences, engineering, medicine, dentistry, agriculture, law, commerce, management, music, performing arts and many others (Sethi et al., 2012). The higher education system in India is made up of universities established by a legislative act (central universities), universities produced by the state legislature (private universities), universities considered to have university status. They have the authority to confer their own degrees. Post-independence, there has been a huge increase in the number of higher education institutes in India. The University Grants Commission (UGC) is the key top body responsible for ensuring the standard of education and overseeing such institutes. Because of such a multitude of institutions offering higher education in India, it becomes necessary to examine the understanding of the importance such institutions give to students for their services offered and the student community's satisfaction with the standard of education and other facilities given by these institutes (Cheney \& Ruzzi, 2005).

In this age of global rivalry, the service sector organizations are increasingly mindful of the loyalty problem with both their internal and external clients, while there are still no measurable involvements in the case with mere business companies. Higher education is deemed part of the service sector because it offers premium learning opportunities and instruction that turns students into highly trained and knowledgeable professionals in many interrelated crossfunctional competencies. In an effort to grab and maintain market share with the rise in research options for students, particularly in higher education, institutes around the world are constantly struggling to provide their students with a unique learning experience (Bernal, 2001). Considering the economic situation, universities and higher education institutes can no longer afford to neglect the interests of their target group of existing and future customers (i.e., their students). Such organizations need a stronger business focus combined with building a favourable picture of themselves in the eyes of their target audience in order to maintain a long- 
lasting, profitable, sustainable edge on the business (Dunleavy et al., 2009).

The current work suggests master level courses in business management as a substitute for higher education for research purposes. It is because the demand for business education in India is projected to be around INR 30 billion by market analysis firms for both campus and distance education. Masters in business administration is one of India's most popular courses including around 1,550 business schools that graduate more than 100,000 management graduates annually (Francis, 2009). Most of these schools are experiencing several challenges, such as increasing tuition rates, critiques of course curricula, and intensified rivalry at both regional and global levels. Under these conditions, both the management and faculty leaders of these business schools are likely to update administrative practices, course curricula and methods of teaching (Aithal, 2015). Hence it is a rational decision to analyze the aspects of the service from which students obtain their understanding, from their interaction throughout the course of their educational path. Therefore, the research intends to examine the fundamental dimensions of service value in Indian business school education along with the effect of these important dimensions on customer satisfaction and student engagement, which will assist the management of these schools in properly allocating scarce capital to ensure better service quality.

\section{MATERIALS AND METHOD}

The research methodology contained a self-administered questionnaire which was distributed among business school graduates. Their answers were subsequently evaluated by means of a key component factor study, and they were given two dimensions of perceived service importance: (a) practical importance and (b) service efficiency.

The questionnaire was comprised of two sections. The first component composed of products that calculated the business benefit in various measurements. Originally 38 measuring items were collected relating to the service dimensions. Then the number of things was decreased to 21 with the assistance of specialists in the field of research and with careful consultation with the academic group of Parul University Business School. The questionnaire was further updated and optimized prior to the final data collection process, based on a pre-test performed on faculty members at the same business school. Ultimately the number of service value measurement items in the final copy of the questionnaire reached 12 items. The second portion of the survey instrument was composed of variables that assessed student satisfaction and student loyalty.

Care was taken to minimize prejudice in the students' answers by allowing them enough time to address the questions. It has also been taken note that the students have no other obligations directly after completing the questionnaire in order to release their minds from any troubled anxiety and any inadvertent feelings. Students were also apprised about the background and goals of the study. In addition, 300 questionnaires from a sample size of 400 were assigned to the students at random. Our research obtained 195 completed questionnaires, 182 of which were available, resulting in a response rate of 93.33 percent, which is acceptable for such survey type. With the help of 5-point Likert scale ranged from 5 (strongly agreed) to 1 (strongly disagreed), the respondents were asked to indicate their degree of agreement with the set of claims about the dimensions of service efficiency and user loyalty. Table 2 shows the detailed characteristics of the samples.

\section{RESULT AND DISCUSSION}

Data obtained from the analysis was characterized in two further phases. In the first phase, the factor analysis was performed using main component analysis with varimax orthogonal rotation for the 12 factors corresponding to the service value measurements. Due to simple operation, an orthogonal rotation was employed in the data analysis of current study. An orthogonal rotation was undertaken with the support of two-item scale that extrapolated student loyalty and student satisfaction. Throughout the second level, with customer satisfaction and student engagement respectively as dependent variables, the component scores of the service value parameters derived from the factor analysis were used as independent variables in two multiple regression analysis. Table 1 elaborates the descriptive statistics of service value items and those of satisfaction and loyalty. 
Table 1. Measurement items used in the study

\begin{tabular}{ll}
\hline Item & Measurement items \\
no. & \\
\hline
\end{tabular}

\section{Service value}

1 Overall quality of the services provided by the university is excellent

2 Educational resources and provisions of the university are sufficient

3 Extensive list of educational programmes combined with several specializations are provided by the university

$4 \quad$ The university has made available the best and state-of-the-art hostel facilities with their ancillary equipments

\section{Student satisfaction}

$5 \quad$ I am happy and please with the educational and other services provided by university I am grateful towards the university for imparting education of the highest quality I am appreciative for successfully carrying out extensive intellectual development within myself ever since I joined this university

8 I am thankful towards all the teaching and supporting staff of my university

\section{Student loyalty}

9 I shall suggest my friends to join this university in some capacity

10 I am interested to enrol for courses offering advanced education in this university

11 I shall re-select my current university if given a chance to select any university today.

12 I have conveyed the advantages of joining this university with my parents and friends.

Table 2. Demographic profile of respondents

\begin{tabular}{lcc}
\hline Variable & No. & \% \\
\hline Gender & 108 & 59.34 \\
Male & 74 & 40.66 \\
Female & & \\
Progress in course work & 128 & 70.32 \\
First year & 54 & 29.68 \\
Second Year & & \\
\hline
\end{tabular}

\section{Results of Factor analysis:}

The rotated factor analysis function matrix revealed two factors measured for around $72 \%$. The precision of all of the parameters was determined using the alpha of the Cronbach. For the element to be accurate, an alpha value of a Cronbach greater than or equivalent to 0.7 is considered appropriate. All the variables except for one Cronbach's alpha had a reasonable value (reliability was similar to o.5). Table 3 highlights the aspects of factor analysis.

There were two variables uncovered by the principal component factor study with Varimax orthogonal rotation for student satisfaction items. A variance of around $58.707 \%$ clarified the unidimensional student satisfaction factor, wherein the value 0.763 was obtained for Cronbach's alpha for the same factor and was considered within acceptable limits. A total variance amounting to $51.985 \%$ clarified over the items of the student loyalty scale being a single factor. The same was clarified upon factor analysis and the value of Cronbach's alpha was calculated at 0.666 for the same factor

\section{A. Regression Analysis}

\section{Regression Model 1:}

The regression analysis used factor score for student satisfaction as the dependent variable and factor score for the service value measurements as the independent variables to analyze the effect of the service value measurements on student satisfaction. In the following section, the regression model is shown below. The regression analysis $\mathrm{F}$ statistics (64.79) suggest that the overall model is significant at a level of 1 per cent. The results also show that both independent variables account for nearly 50 per cent. At 1 per cent level, the beta coefficients of the two independent variables are significant. The overall result of regression analysis (model 1) used in the study is revealed in Table 5 .

\section{Regression Model 2:}

The regression model 2 was used to examine the effect of the service value dimensions on student loyalty. The regression model 2 employed the student loyalty factor score. The overall result of regression analysis (model 2) used in the study is revealed in Table 6.

The F statistic (57.53930) indicated that the average result is statistically significant at $1 \%$ level of significance in the regression model 2. Furthermore, the result suggested that 
the independent variables like service quality and functional value exhibit statistical significance at $1 \%$ level of significance.

The current analysis of the items of service quality in the higher education institutes (Indian business school) disclosed two dimensions that are in line with the existing observations published in the literature (Nadiri et. al., 2009; Seng \& Ling, 2013; Zafiropoulos \& Vrana, 2008; Yousapronpaiboon, 2014; Farahmandian et al., 2013). Interesting findings were provided by the regression analysis. Variability of customer satisfaction is mainly clarified by the practical importance and the level of support the business school offers. This is consequently observed that the measurements of the service interest also have a clear impact on customer engagement as well as an indirect influence influenced by consumer satisfaction.
The research results in major consequences. Knowledge of the dimensions of the service value can help the management of the business school to properly allocate both capital and human resources in providing better service. The most significant dimensions of importance affecting both customer retention and loyalty were identified to be practical interest and standard of service. Consequently, sufficient focus and enhancement in these dimensions will potentially allow the management to boost the understanding of service value among current and future student base (Yusof et. al., 2012; Sultan \& Wong, 2011; Sadeh \& Garkaz, 2015). As stated earlier that having a happy and committed client base in the retail sector is critical for a business school; proper focus on service performance improvement may contribute to beneficial results and eventually can be an avenue for gaining competitive advantage.

Table 3. Rotated factor matrix

\begin{tabular}{|c|c|c|c|c|c|}
\hline Factors & Item no. & $\begin{array}{c}\text { Measurement items } \\
\text { (service value dimensions) }\end{array}$ & Loadings & Variance & Reliability \\
\hline \multirow[t]{2}{*}{$\begin{array}{l}\text { Functional } \\
\text { Value }\end{array}$} & 3 & $\begin{array}{l}\text { Extensive list of educational programmes combined } \\
\text { with several specializations are provided by the } \\
\text { university. }\end{array}$ & 0.736 & $13.92 \%$ & 0.815 \\
\hline & 1 & $\begin{array}{l}\text { Overall quality of the services provided by the } \\
\text { university is excellent. }\end{array}$ & 0.713 & $13.21 \%$ & 0.818 \\
\hline \multirow[t]{2}{*}{$\begin{array}{l}\text { Service } \\
\text { Quality }\end{array}$} & 4 & $\begin{array}{l}\text { The university has made available the best and state- } \\
\text { of-the-art hostel facilities with their ancillary } \\
\text { equipments. }\end{array}$ & 0.707 & $9.62 \%$ & 0.751 \\
\hline & 2 & $\begin{array}{l}\text { Educational resources and provisions of the university } \\
\text { are sufficient. }\end{array}$ & 0.456 & $7.05 \%$ & 0.549 \\
\hline
\end{tabular}

Table 4. Unidimensionality of student satisfaction and student loyalty

\begin{tabular}{|c|c|c|c|c|c|}
\hline Factors & Item no. & Measurement items & Loadings & Variance & Reliability \\
\hline \multirow{5}{*}{$\begin{array}{l}\text { Student } \\
\text { Satisfaction }\end{array}$} & 7 & I am appreciative for successfully carrying out & 0.809 & $58.68 \%$ & 0.759 \\
\hline & & $\begin{array}{l}\text { extensive intellectual development within myself } \\
\text { ever since I joined this university. }\end{array}$ & & & \\
\hline & 5 & $\begin{array}{l}\text { I am happy and please with the educational and } \\
\text { other services provided by university. }\end{array}$ & 0.769 & & \\
\hline & 8 & $\begin{array}{l}\text { I am thankful towards all the teaching and } \\
\text { supporting staff of my university. }\end{array}$ & 0.749 & & \\
\hline & 6 & $\begin{array}{l}\text { I am grateful towards the university for imparting } \\
\text { education of the highest quality. }\end{array}$ & 0.719 & & \\
\hline $\begin{array}{l}\text { Student } \\
\text { Loyalty }\end{array}$ & 12 & $\begin{array}{l}\text { I have conveyed the advantages of joining this } \\
\text { university with my parents and friends. }\end{array}$ & 0.849 & $51.88 \%$ & 0.62 \\
\hline
\end{tabular}




\begin{tabular}{llll}
\hline 9 & $\begin{array}{l}\text { I shall suggest my friends to join this university in } \\
\text { some capacity. }\end{array}$ & 0.848 \\
11 & $\begin{array}{l}\text { I shall re-select my current university if given a } \\
\text { chance to select any university today. }\end{array}$ & 0.549 \\
10 & $\begin{array}{l}\text { I am interested to enrol for courses offering } \\
\text { advanced education in this university }\end{array}$ & 0.551 \\
\hline
\end{tabular}

Table 5. Regression Model 1 summary

\begin{tabular}{lcccc}
\hline $\begin{array}{l}\text { Independent variables } \\
\text { (factors) }\end{array}$ & Coefficient & Standard error & t-statistic & Prob. \\
\hline (Constant) & 0.0127 & 0.0371 & 0.3459 & 0.7287 \\
Functional Value & 0.4751 & 0.0369 & 12.794 & 0.0048 \\
Service Quality & 0.1251 & 0.0384 & 3.198 & 0.0011 \\
\hline
\end{tabular}

Note. $R^{2}=0.4993 ;$ Adjusted $R^{2}=0.5011 ; F$-value=64.79; Sig. F=0.oooo; dependent variable=student satisfaction

Table 6. Regression Model 2 summary

\begin{tabular}{|c|c|c|c|c|}
\hline $\begin{array}{l}\text { Independent variables } \\
\text { (factors) }\end{array}$ & Coefficient & Standard error & t-statistic & Prob. \\
\hline (Constant) & -0.005 & 0.032 & -0.19 & 0.841 \\
\hline Functional Value & 0.491 & 0.034 & 13.89 & 0.0001 \\
\hline Service Quality & 0.402 & 0.403 & 10.91 & 0.0001 \\
\hline
\end{tabular}

Note. $R^{2}=0.4593 ;$ Adjusted $R^{2}=0.4569 ; F$-value=57.53930; Sig. $F=0.0001 ;$ dependent variable=student loyalty

\section{CONCLUSION}

The current study was undertaken due to the void in the existing literature where there is no agreement on the various dimensions of value experience in services in India. The concept also needs consistency in terms of interpretation and operationalization given the plethora of literature on perceived interest of facilities. Consequently, the article refers to the literature in such a way as to address certain basic aspects of service efficiency in the business school education systems.

\section{ACKNOWLEDGEMENT}

We, the authors acknowledge the support and services provided by the Parent University.

\section{REFERENCES}

Aithal, PS 2015, 'Comparative study on MBA programmes in private \& public universities - a case study of MBA programme plan of Srinivas University', International Journal of Management Sciences and Business Research, vol. 12, no. 12, pp. 106-122.

Bernal, DD 2001, 'Learning and living pedagogies of the home: the mestiza consciousness of Chicana students', International Journal of Qualitative Studies in Education, vol. 14 , no. 5, pp. 623-639.
Cheney, GR, Ruzzi, BB \& Muralidharan, K 2005, 'A profile of the Indian education system', Prepared for the New Commission on the Skills of the American Workforce.

Dunleavy, M, Dede, C \& Mitchell, R 2009, 'Affordances and limitations of immersive participatory augmented reality simulations for teaching and learning', Journal of Science Education and Technology, vol. 18, no. 1, pp. 7-22.

Farahmandian, S, Minavand, H \& Afshardost, M 2013, 'Perceived service quality and student satisfaction in higher 
education', Journal of Business and Management, vol. 12, no. 4, pp. 65-74.

Francis, R 2012, 'Business communication courses in the MBA curriculum: a reality check', International Proceedings of Economic Development \& Research, vol. 33, pp. 188-192.

Nadiri, H, Kandampully, J \& Hussain, K 2009, 'Students' perceptions of service quality in higher education', Total Quality Management, vol. 20, no. 5, pp. 523-535.

Reddy, KS, Xie, E \& Tang, Q 2016, 'Higher education, highimpact research, and world university rankings: a case of India and comparison with China', Pacific Science Review B: Humanities and Social Sciences, vol. 2, no. 1, pp. 1-21.

Sadeh, E \& Garkaz, M 2015, 'Explaining the mediating role of service quality between quality management enablers and students' satisfaction in higher education institutes: the perception of managers', Total Quality Management \& Business Excellence, vol. 26, no. 11, pp. 1335-1356.

Seng, E \& Ling, T 2013, 'A statistical analysis of education service quality dimensions on business school students' satisfaction', International Education Studies, vol. 6, no. 8, pp. 136-146.

Sethi, S, Ghuman, R \& Ukpere, W 2012, 'A critical appraisal of higher education and economic development in India', African Journal of Business Management, vol. 6, no. 23, pp. 6795-6801.

Sultan, P \& Wong Y 2011, 'Service quality in a higher education context: antecedents and dimensions', International Review of Business Research Papers, vol. 7 , no. 2, pp. 11-20.

Yousapronpaiboon K 2014, 'SERVQUAL: Measuring higher education service quality in Thailand', Procedia-Social and Behavioral Sciences, vol. 21, no. 116, pp. 1088-1095.

Yusof, A, Hassan, Z, Rahman, S \& Ghouri, A 2012, 'Educational service quality at public higher educational institutions: a proposed framework and importance of the sub-dimensions', International Journal of Economics Business and Management Studies, vol. 1, no. 2, pp. 36-49. Zafiropoulos, C \& Vrana, V 2008, 'Service quality assessment in a Greek higher education institute', Journal of business economics and management, vol. 9, no. 1, pp. 33-45. 